\title{
The Correlations of Age, Weight, Body Mass Index (BMI), Dialized Volume and Total Protidemia, With Somatic Variables in a Population of 27 Females and 34 Males Undergoing Chronic Peritoneal Dialysis
}

\author{
Giancarlo Ruggieri
}

\begin{abstract}
Premise - The purpose of the present paper bases on the study of the correlations existing between age, weight, body mass index (BMI), dialized volume and total protidemia with a series of somatic variable, many of them linked to nutrition conditions : for instance, the correlation between age and creatininemia : the plasmatic value of this last depends on renal function but also on the muscle mass, that is depending in its turn on the age and also by the nutrition conditions : a significant correlation between age and creatininemia, in presence of a normal creatininemia, let us know the degree of body nutrition, Therefore the not significant correlations show the absence of an adequate dependence between the predicting variable and the predicted response : in the case of the example above, it should be probable that the influence of other physic conditions caused the failure of a direct relationship between age and creatininemia.

Index Terms — body mass index (BMI), Protidemia.
\end{abstract}

\section{INTRODUCTION}

Method - The following correlations were performed in males and females according to it follows : 1) predictor : age - responders : weight, BMI, dialized volume, creatininemia, azotemia, total protidemia albuminemia, cholesterolemia, triglyceridemia, hemoglobin hematocrit 2) predictor : weight - responders : creatininemia, azotemia, total protidemia, albuminemia ,cholesterolemia, triglyceridemia, hemoglobin, hematocrit. 3) predictor :BMI - responders : dialized volume, creatininemia, azotemia, total protidemia, albuminemia, cholesterolemia, triglyceridemia, hemoglobin, hematocrit 4) predictor : dialized volume - responders : dialized volume, creatininemia, azotemia, total protidemia, albuminemia, cholesterolemia, triglyceridemia, hemoglobin hematocrit 5) predictor : total protidemia - responders : creatininemia, azotemia, albuminemia cholesterolemia, triglyceridemia, hemoglobin, hematocrit. Summarizing, the selected predicting variables are : age, weight, BMI, dialized volume, total protidemia, each of them correlated with the all remaining variables.

The results of the significant correlations, operated by linear regressions are reported for males and females in the following tables : 
The Correlations of Age, Weight, Body Mass Index (BMI), Dialized Volume and Total Protidemia, With Somatic Variables in a Population of 27 Females and 34 Males Undergoing Chronic Peritoneal Dialysis

\begin{tabular}{|c|c|c|c|c|c|c|c|}
\hline \multicolumn{8}{|c|}{ Table I Males and Females : the somatic data attaining significant regressions } \\
\hline $\begin{array}{l}\text { Males significant } \\
\text { regressions }\end{array}$ & & $\mathrm{p}$ & scores & Females significant regressions & & $\mathrm{p}$ & scores \\
\hline Age & $\begin{array}{l}\text { dialized } \\
\text { volume }\end{array}$ & 0,001 & 5 & Age & $\begin{array}{l}\text { dialized } \\
\text { volume }\end{array}$ & 0,027 & 3 \\
\hline Age & creatininemia & 0,049 & 5 & Age & trigliceridemia & 0,037 & 3 \\
\hline BMI & creatininemia & 0,038 & 3 & BMI & Creatininemia & 0,014 & 3 \\
\hline BMI & azotemia & 0,012 & 3 & total protidemia & Hematocrit & 0,033 & 3 \\
\hline BMI & $\begin{array}{c}\text { total } \\
\text { protidemia }\end{array}$ & 0,018 & 3 & & & mean & 3 \\
\hline dialized volume & hemoglobin & 0,047 & 3 & & & $\mathrm{SD}$ & 0 \\
\hline
\end{tabular}

\begin{tabular}{|l|c|c|c|}
\hline total protidemia & albuminemia & 0 & 7 \\
\hline Weight & creatininemia & 0,009 & 5 \\
\hline Weight & azotemia & 0,011 & 3 \\
\hline \multirow{2}{*}{ Weight } & $\begin{array}{c}\text { total } \\
\text { protidemia }\end{array}$ & 0,005 & 5 \\
\hline \multicolumn{2}{|l}{} & mean & 4,2 \\
\cline { 2 - 4 } & SD & 1,4 \\
\cline { 2 - 4 }
\end{tabular}

The scores given to the $\mathrm{p}$ values of regressions are used by the Author here and in past published papers with the purpose to 0,009 and 0,001 , score $=5, \mathrm{p}$ comprised between 0,0001 and 0,000 or lower to 0,000 , score $=7$. At first, the scores had different values, because calculated according to the formula give a numerical significance to the $\mathrm{p}$ values attained by the regressions, this to let the possibility to numerically compare the attained level of the $\mathrm{p}$ values of significant or not significant correlations. The scores are established according to the following scale : $\mathrm{p}=$ or $>0,05$, score $=0 ; \mathrm{p}$ comprised $:$ score $=(p$ value $x 100) / 7:$ the present score of $p=0,005$ is 5 , in the past use, the corresponding score was $(0,005 \times 100) / 7$ $=0,071$. In the following table is reported the result of the comparison of scores attained by the significant regressions males versus females.

between 0,049 and 0,01, score $=3$, p comprised between

\begin{tabular}{|c|c|c|}
\hline \multicolumn{3}{|l|}{$\begin{array}{l}\text { Table II - Test T by Minitab - Scores of } \\
\text { significant regressions males versus females }\end{array}$} \\
\hline T-Value & DF & P-Value \\
\hline 2,57 & 8 & $\mathbf{0 , 0 3 3}$ \\
\hline
\end{tabular}

The results of comparing the scores of all regressions males versus females are resumed in the following Table III

\begin{tabular}{|c|c|c|c|c|c|c|}
\hline \multicolumn{6}{|c|}{ Table III - Comparison of scores of all regressions males versus females } \\
\hline \multicolumn{3}{|c|}{ males } & \multicolumn{2}{c|}{ females } & \multicolumn{4}{c|}{ T Test } \\
\hline mean & SD & mean & SD & T-Value & DF & P-Value \\
\hline 0,98 & 1,84 & 0,34 & 0,96 & 2,05 & 64 & $\mathbf{0 , 0 4 5}$ \\
\hline
\end{tabular}

A similar comparison was performed concerning the not significant regressions, whose results are reported in the following

Table IV. The data compared are the $\mathrm{p}$ values and not the scores, taking into account that the scores of not significant $\mathrm{p}$ values are $=0$.

\begin{tabular}{|c|c|c|c|c|c|c|}
\hline \multicolumn{7}{|c|}{ Table IV - Comparison of p values not significant regressions } \\
\hline \multicolumn{3}{|c|}{ males } & \multicolumn{2}{c|}{ females } & \multicolumn{3}{c|}{ T Test } \\
\hline mean & SD & mean & SD & T-Value & DF & P-Value \\
\hline 0,45 & 0,25 & 0,47 & 0,25 & $-0,38$ & 86 & 0,708 \\
\hline
\end{tabular}


It has to note that the $\mathrm{p}$ value of $\mathrm{T}$ test is very high $(0,708)$, that is to say that the resulting $\mathrm{p}$ values of not significant regressions are quite similar between males and females.

The comparison of results of the regression, all concerning somatic variables, attain a significant difference $(p=0,045)$ between males and females on base of scores values that are strongly correlated with $\mathrm{p}$ values, Furthermore, the comparison of the means of the scores attained a significant value of difference, $p=0,039$. From what above, it is possible to note that, even not relevant, a significant difference between male and female regressions does result. At same time, no differences concerning the not significant regressions resulted, $\mathrm{p}=0,708$. The only regression with significant result in males as in females was creatininemia versus weight, with $\mathrm{p}=0,01$ in males and $\mathrm{p}=0,012$ in females. Males attained 11 significant and 33 not significant regressions out of 44, while females attained 5 significant and 39 not significant regressions out of 44 . It should be useful to understand in depth the causes of the difference between males and females of the relationships concerning the somatic data : It could be possible to argue that other somatic components, not considered in the present elaboration, and relevant in the somatic conditions of females, negatively influenced the somatic data of females considered in the present paper, with the consequent very low relationship between predicting and responding variables. The Author has to observe that in many previous papers, similarly based on a population undergoing chronic peritoneal dialysis, where comparison of data of males versus corresponding data of females was performed, only marginal differences resulted.

\section{REFERENCES}

[1] Ruggieri G ed altri - Progetto di studio di alcuni aspetti economici della Dialisi - 1993 Atti del VII Congresso Nazionale di Dialisi peritoneale Ruggieri G Spinelli C d'Adamo G Franceschelli L Testa MA - Stato nutrizionale dei pazienti in CAPD nel Lazio - 1993 Riv. Eur. Sci. Med. $15(3-4), 149$

[2] Ruggieri G Di Girolamo M Messina A Filippini A Rocca AR Esposto C Utzeri G Spinelli C d'Adamo G - Valutazione della massa muscolare e del grasso in emodialisi ed in dialisi peritoneale mediante risonanza magnetica nucleare per immagini : possibilità di predire i dati RMN da variabili di usuale utilizzo e confronto fra soggetti in emodialisi ed in dialisi peritoneale - 2002 Atti delle Giornate Nefrologiche Romane

[3] Filippini A Rocca AR Messina A Rossin G Ruggieri G - Extracellular Mass/Body Cell Mass (ECM/BCM) Ratio by Tetrapolar Body Impedance Analysis (BIA) may be a Marker of Malnutrition in CAPD Patients - 1996 Perit Dial Trans 16, S 2 Abstrs XVIth Annual Conference of Peritoneal Dialysis, Seattle, Washington
[4] Ruggieri G Di Girolamo M Messina A Filippini A Rocca AR Esposto C Utzeri G Spinelli C d'Adamo G - Valutazione della massa muscolare e del grasso in emodialisi ed in dialisi peritoneale mediante risonanza magnetica nucleare per immagini : possibilità di predire i dati RMN da variabili di usuale utilizzo e confronto fra soggetti in emodialisi ed in dialisi peritoneale - 2002 Atti delle Giornate Nefrologiche Romane 